\title{
EASILY LEACHABLE RARE EARTH ELEMENT PHASES IN THE PARNASSUS-GIONA BAUXITE DEPOSITS, GREECE
}

\author{
Mouchos E. ${ }^{1}$, Wall F. ${ }^{1}$, Williamson B.J. ${ }^{1}$ and Palumbo-Roe B. ${ }^{2}$ \\ ${ }^{1}$ Camborne School of Mines, University of Exeter, Penryn,UK, em415@exeter.ac.uk, \\ f.wall@exeter.ac.uk,.j.j.williamson@exeter.ac.uk \\ ${ }^{2}$ British Geological Survey, Environmental Science Centre, Keyworth, Nottingham, UK, \\ bpal@bgs.ac.uk
}

\begin{abstract}
The Parnassus-Giona karst bauxite deposits contain significant concentrations of rare earth elements (400-500 ppm). Preliminary results from a pilot leaching study show that between 19 and $47 \%$ of rare earth elements in the bauxite are easily leachable using ion exchange agents such as ammonium sulphate.

Keywords: Rare earth element leaching, bauxite, Parnassus-Giona.
\end{abstract}

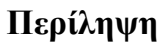

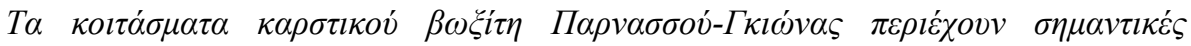

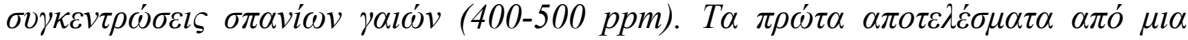

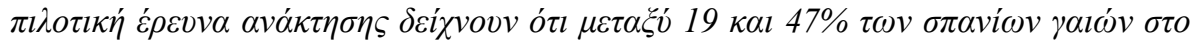

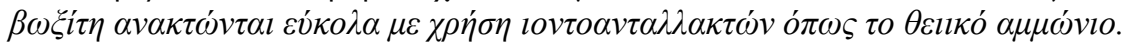

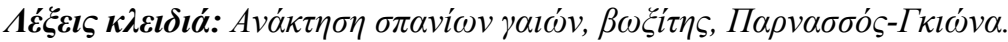

\section{Introduction}

Rare earth elements (REE) have been recently classed as "critical metals" because of rising global demand, due to their use in many new, green and emerging technologies (EC, 2014), and because of a near monopoly ( $97 \%$ ) in supply from China (Chakhmouradian and Wall, 2012; Kynicky et al., 2012). Other countries producing REE, in order of decreasing production are USA, India, Australia, Russia, Thailand, Malaysia and Vietnam (USGS, 2015). In addition there are currently extremely low rates of recycling, less than $1 \%$ (Chakhmouradian and Wall, 2012). These factors increase the urgency to identify alternative REE resources. Most of the world's supply of heavy REE (HREE) comes from around 200 mines working so-called ion-adsorption deposits (or weathered crust elution-deposited rare earth ores) across southern China (Jiangxi, Hunan, Guangdong, Guangxi and Fujian provinces) (Bao and Zhao, 2008; Chi and Tian, 2008). These deposits were formed by in situ lateritic weathering of REE rich felsic rocks (mainly granites), which led to the formation of weathered profiles containing residual REE-clays (Kynicky et al., 2012; Moldoveanu and Papangelakis, 2012). A proportion of the REE in these deposits is adsorbed onto the surfaces of clays. REE can be easily removed from the clays using ion exchange agents such as magnesium chloride, EDTA or ammonium sulphate.

Laterites and bauxites are ores formed in tropical soils by weathering processes and are enriched in iron and aluminum, respectively (Retallack, 2010). Some lateritic deposits are also mined for their nickel, gold, niobium, phosphorus and REE concentrations (Freyssinet et al., 2005; Wall, 2014). 
Although laterites and bauxites of Central Greece contain REE (Valeton et al., 1987), they are not mined for REE because their concentrations are relatively low. The aim of the current study was to assess the concentrations and leachability of REE in Greek bauxites, which are currently being mined as a commercial source of aluminum, and for which Greece has large reserves $\left(9^{\text {th }}\right.$ country worldwide and $1^{\text {st }}$ in the EU according to the USGS (2015)). Although there have been few studies on the REE potential of Greek bauxites, a number have found significant concentrations in the red mud waste from their processing using the Bayer Process (e.g. Ochsenkühn-Petropulu et al., 1994; Deady et al., 2014; Borra et al., 2015; Gamaletsos et al., 2016).

The main differences between bauxite, red mud waste and ion-absorption clays is that bauxite contains significantly lower concentrations of $\mathrm{Si}$ compared with ion-absorption clays, and significantly higher levels of Al compared with red mud. Fulford et al. (1991) developed a protocol for the extraction of REE from Jamaican red mud waste using sulphur dioxide. Although this method showed that REE appear to be readily leachable from red mud waste using diluted mineral acids, they cannot be leached from bauxite under the same experimental conditions (Fulford et al., 1991; Binnemans et al., 2013). However, Gamaletsos et al. (2016) recently achieved a significant recovery of REE from both Greek bauxites and red muds using acetic acid. The aim of this paper is to present preliminary results from a pilot leaching study of Greek bauxite using an ammonium sulphate $\left[\left(\mathrm{NH}_{4}\right)_{2} \mathrm{SO}_{4}\right]$ solution as leaching agent.

\section{Greek Bauxite Characteristics}

The most economically important bauxite deposits in Greece are those of the Parnassus-Giona area (B3 or $3^{\text {rd }}$ bauxite horizon). These belong to the Mediterranean-type allochthonous karst bauxites, which occur as layers or pockets and were formed by lateritic weathering processes (Valeton et al., 1987; Tsirambides and Filippidis, 2012). The mineralogy of these bauxites is dominated by the aluminium oxide monohydrates boehmite $[(\gamma-\mathrm{AlO}(\mathrm{OH})]$ and diaspore $[(\alpha-\mathrm{AlO}(\mathrm{OH})]$, the iron oxides hematite $\left(\mathrm{Fe}_{2} \mathrm{O}_{3}\right)$ and goethite $[\mathrm{FeO}(\mathrm{OH})]$, the titanium oxide anatase $\left(\mathrm{TiO}_{2}\right)$, and secondary minerals including kaolinite $\left[\mathrm{Al}_{2} \mathrm{Si}_{2} \mathrm{O}_{5}(\mathrm{OH})_{4}\right]$ among others (Valeton et al., 1987; Tsirambides and Filippidis, 2012). The Parnassus-Giona bauxite contains up to 5\% of kaolinite as well as lesser amounts of other clay minerals such as illite and chamosite (Tsirambides and Filippidis, 2012; Laskou and Economou-Eliopoulos, 2013). Kaolinite occurs locally as mixtures with Al hydroxides. Low pressure/low temperature alteration of bauxite grains and matrix, possibly aided by down-flowing siliceous waters through pores, cracks and fissures, results in kaolinisation (Dangić, 1988).

Greek bauxite deposits contain an average of approximately 400-500 ppm REE (OchsenkühnPetropoulou et al., 1994; Deady et al., 2014). REE are found at both detrital and authigenic REEbearing minerals in bauxite. The latter are significantly more abundant and usually minute in size $(<1 \mu \mathrm{m})$, occasionally forming larger aggregates or occurring as micropore and fissure fillings (Maksimović and Pantó, 1996). The authigenic REE-bearing minerals reported at the ParnassusGiona bauxite are LREE fluorocarbonate minerals of the bastnäsite $\left((\mathrm{Ce}, \mathrm{La}) \mathrm{CO}_{3} \mathrm{~F}\right)$ and parasite $\left(\mathrm{Ca}(\mathrm{Ce}, \mathrm{La})_{2}\left(\mathrm{CO}_{3}\right)_{3} \mathrm{~F}_{2}\right)$ group (Gamaletsos et al., 2011; 2016). On the other hand, the detrital ones are the LREE phosphates rhabdophane $\left((\mathrm{Ce}, \mathrm{La}) \mathrm{PO}_{4} \cdot\left(\mathrm{H}_{2} \mathrm{O}\right)\right)$ and florencite $\left(\mathrm{CeAl}_{3}\left(\mathrm{PO}_{4}\right)_{2}(\mathrm{OH})_{6}\right)$, and the Y-phosphates churchite $\left(\mathrm{YPO}_{4} \cdot 2\left(\mathrm{H}_{2} \mathrm{O}\right)\right)$ and xenotime $\left(\mathrm{YPO}_{4}\right)($ Laskou and Andreou, 2003). The crystallisation of authigenic REE-bearing minerals towards the base of the bauxite deposits occurs due to the downward transport of relatively mobile elements (including the REE) (Valeton et al., 1987; Ochsenkühn et al., 1991; Maksimović and Pantó, 1996; Deady et al., 2014). Although per descensum enrichment results occasionally in very high REE concentrations near the limestone bedrock, it is not a standard feature of every bauxite deposit.

\section{Materials and Methods}

Bauxite samples were collected from the upper parts of Delphi-Distomon S.A. (subsidiary of Aluminium of Greece S.A.) underground mines and were analyzed for their trace element contents by ICP-MS. The B3 ( $3^{\text {rd }}$ bauxite horizon) active mines were selected due to their importance for the 
bauxite exploitation in Greece. Samples Baux 1 and Baux 2 were collected at an altitude of $577 \mathrm{~m}$ and $500 \mathrm{~m}$, and at $4.5 \mathrm{~m}$ and $9.5 \mathrm{~m}$ above the chamber floor respectively. However, both profiles have a greater depth given that "room-and-pillar" mining progresses vertically following the slope of the deposit. Preparation of the samples was carried out at the Camborne School of Mines (Penryn, UK), whilst sample preparation, by lithium borate fusion followed by acid digestion protocol (LF100 analysis for refractory elements and REEs), and ICP-MS analysis was carried out at Acme Labs (Canada).

In order to investigate the potential presence of adsorbed REE cations in bauxite the ammonium sulphate extraction method from the sequential extraction procedure presented in Sanematsu et al. (2013) was used. Sanematsu et al. (2013) used a modified BCR method of Rauret et al. (1999, 2000) for ion-adsorption clays in Thailand. More precisely, they substituted the first step of the BCR method for one using ammonium sulphate, which is also used for cation exchange at many of the mines in China. The first step was carried out at a slightly acidic $\mathrm{pH}$ that may also dissolve some of the carbonate. Preparation and analysis of the leachates was carried out at the British Geological Survey (Keyworth, UK). The REE leaching protocol used in the current paper is the following:

1. $1 \mathrm{~g}$ of sample is placed in a $50 \mathrm{ml}$ centrifuge tube

2. $40 \mathrm{ml} \pm 0.1 \mathrm{ml}$ volume of $0.5 \mathrm{M}\left(\mathrm{NH}_{4}\right)_{2} \mathrm{SO}_{4}$ solution added

3. Tube shaken to achieve a suspension

4. Adjust the $\mathrm{pH}$ to 4 by adding $\mathrm{H}_{2} \mathrm{SO}_{4}$

5. $16 \mathrm{~h}$ end-over-end shaking

6. Centrifugation of tubes for $20 \mathrm{mins}$ at $3000 \mathrm{rpm}$ (or until supernatant/solid separation is obtained)

7. Allow any residual suspended solid to settle for 15 mins

8. An aliquot from the tube is sampled and the sampled eluate is filtered through a $0.45 \mu \mathrm{m}$ filter

9. The filtered solution is acidified using $\mathrm{HNO}_{3}$ and analysed for REE with ICP-MS

\section{Results}

The two Greek bauxite samples are enriched in light REE (LREE) with approximately 600 ppm of REE in total. The extraction by $0.5 \mathrm{M}\left(\mathrm{NH}_{4}\right)_{2} \mathrm{SO}_{4}$ at pH4 leached $19 \%(114 \mathrm{ppm})$ and $47 \%(278$ ppm) of total REE from Baux 1 and Baux 2 samples, respectively (Table 1). Chondrite normalized REE patterns of both bauxite samples and their leachates show a positive Ce anomaly and a negative $\mathrm{Eu}$ anomaly, which seem to be common in the Parnassus-Giona bauxites and red muds (Ochsenkühn-Petropulu et al., 1994; Laskou and Andreou, 2003; Deady et al., 2014). Chondritenormalized data plotted on a graph also show that a higher proportion of LREE can be leached compared with HREE (Figure 1). Leaching results show that the two samples have significant differences in the proportion of the REE being leached. More precisely, ammonium sulphate leached almost the same proportion of HREE (19\%) from the two bauxite samples, whereas it leached higher amounts of LREE from Baux 2 sample (52\%) compared with those of Baux 1 sample (19\%). Nevertheless, the total REE amount leached does not reach the $500 \mathrm{ppm}$ of leachable REE that is required by Bao and Zhao (2008) to satisfy the definition of ion-adsorption ore. 


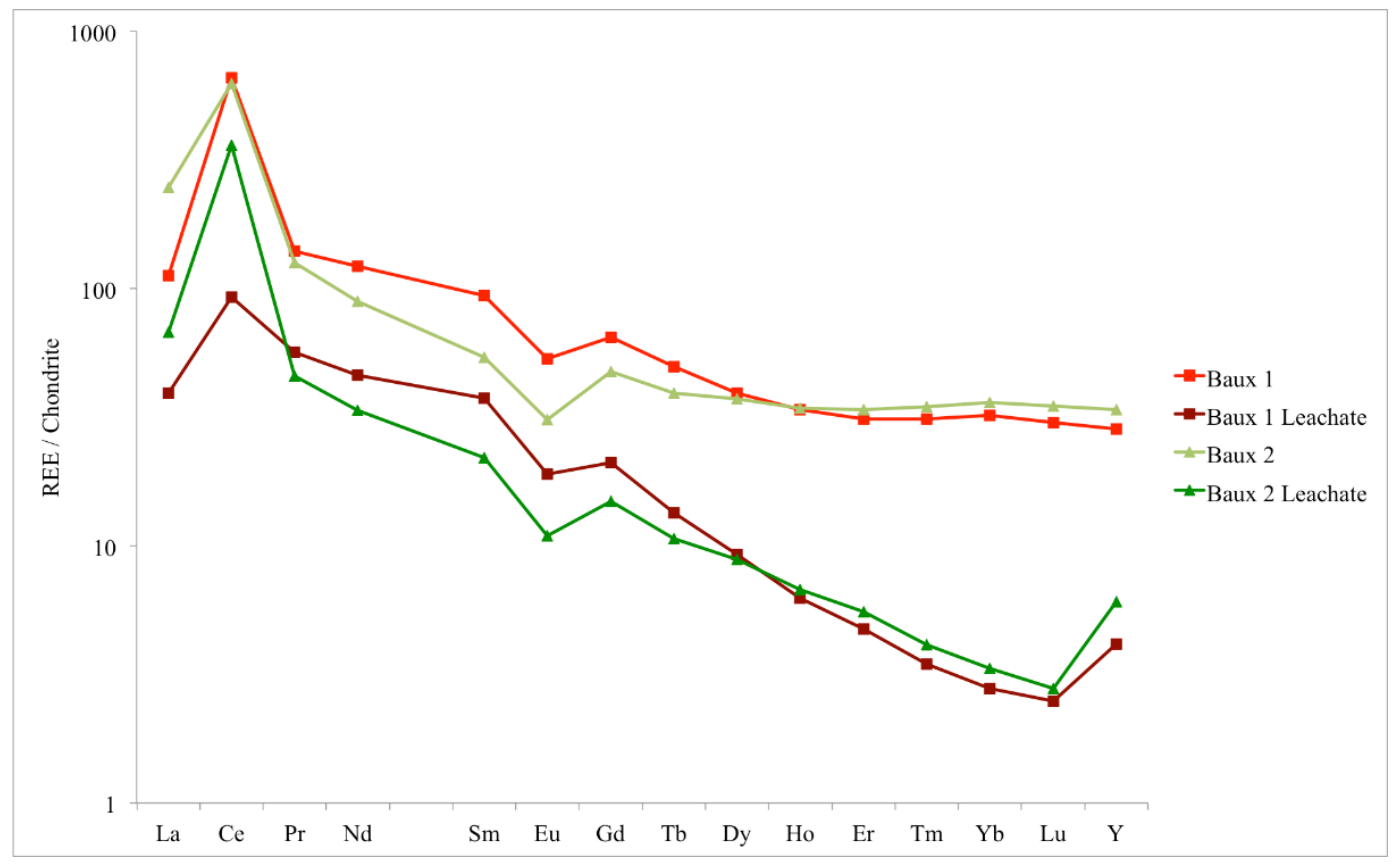

Figure 1 - Chondrite-normalized (McDonough and Sun, 1995) REE patterns in Greek bauxite samples and leachates.

LREE occur as very fine, crystalline, slightly soluble LREE carbonate/hydroxycarbonate minerals in the bauxite samples leached, usually forming clusters or filling micropores and fissures (Figure 2). Ammonium sulphate is supposed only to exchange cations from the surface of minerals and not dissolve them. However, at the leaching experimental conditions of this study ( $\mathrm{pH} \mathrm{4}$ ), it may have caused some dissolution of these minerals. Consequently, preferential LREE fractionation into solution, relative to HREE, may have been caused by a partial dissolution of the LREE minerals in the bauxite. In addition the lanthanide contraction that controls the grouping of LREE and HREE into different mineral hosts may also have an effect on the cation exchange behaviour.
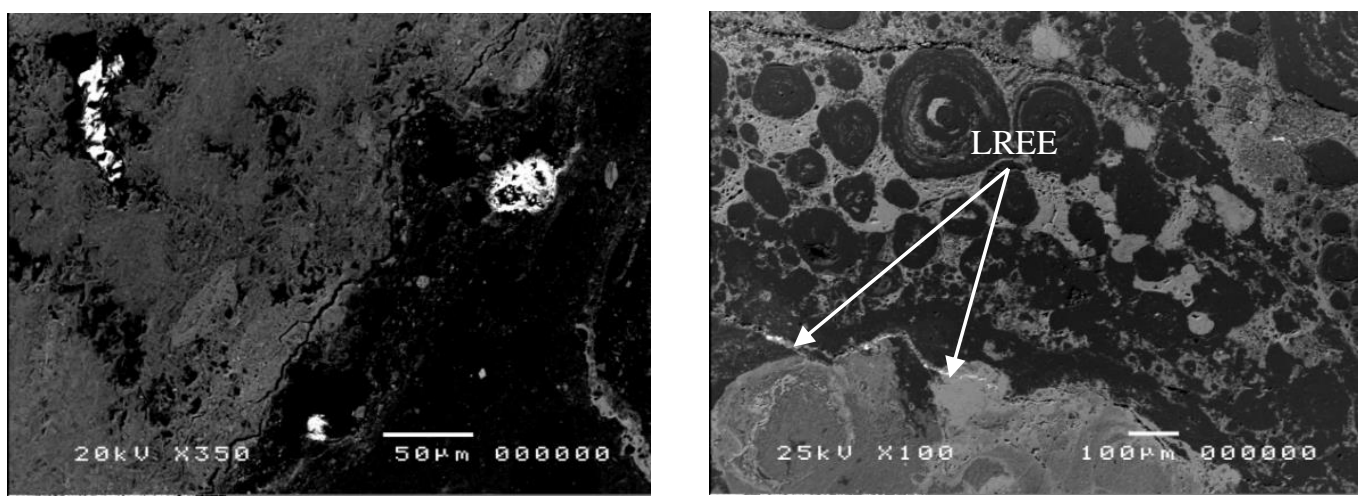

Figure 2 - BSE-SEM images of LREE carbonate/hydroxycarbonate minerals in Greek bauxite samples (Wall et al., 2014).

\section{Discussion}

Concentrations of REE in Greek bauxite and red muds are low (usually <1,000 ppm) compared with carbonatite deposits such as Mountain Pass and Mount Weld, which have grades of around 80,000 ppm REE (Wall, 2014). They are more comparable to those in lower grade Chinese ion-adsorption 
clay deposits that usually contain 500-2,000 ppm REE (Kynicky et al., 2012; Moldoveanu and Papangelakis, 2012). Heterogeneity and differences in the chemistry of bauxite and red mud make it difficult to develop a common REE leaching method that can extract $100 \%$ of REE from bauxite or its by-products. Currently, the focus of REE extraction is mainly on red mud as it has double the REE concentrations compared with the initial bauxite (Ochsenkühn-Petropoulou et al., 1994). Various studies have achieved significant results towards this direction using acids (e.g. Ochsenkühn-Petropoulou et al., 1996; Borra et al., 2015; Gamaletsos et al., 2016), but these still need more development in order to be economically feasible and able to be established as parts of aluminium's industry.

Table 1 - Leaching results for REE, showing the leached amounts of REE after using a protocol based on Sanematsu et al. (2013).

\begin{tabular}{|l|r|r|r|r|r|r|}
\hline & $\begin{array}{c}\text { Baux 1 } \\
(\mathbf{p p m})\end{array}$ & $\begin{array}{c}\text { Baux 1 } \\
\text { Leachate } \\
(\mathbf{p p m})\end{array}$ & $\begin{array}{c}\text { Baux 1 } \\
\text { REE \% } \\
\text { Leached }\end{array}$ & $\begin{array}{c}\text { Baux 2 } \\
\mathbf{p p m})\end{array}$ & $\begin{array}{c}\text { Baux 2 } \\
\text { Leachate } \\
(\mathbf{p p m})\end{array}$ & $\begin{array}{c}\text { Baux 2 } \\
\text { REE \% } \\
\text { Leached }\end{array}$ \\
\hline La & 26.70 & 9.31 & 34.88 & 58.80 & 16.01 & 27.22 \\
\hline Ce & 404.20 & 56.82 & 14.06 & 384.80 & 221.84 & 57.65 \\
\hline Pr & 13.01 & 5.24 & 40.28 & 11.68 & 4.25 & 36.41 \\
\hline Nd & 55.80 & 21.09 & 37.80 & 40.70 & 15.36 & 37.74 \\
\hline Sm & 13.91 & 5.55 & 39.91 & 7.99 & 3.26 & 40.81 \\
\hline Eu & 3.01 & 1.07 & 35.48 & 1.74 & 0.61 & 35.31 \\
\hline Gd & 12.88 & 4.19 & 32.55 & 9.47 & 2.96 & 31.21 \\
\hline Tb & 1.80 & 0.48 & 26.91 & 1.42 & 0.38 & 27.03 \\
\hline Dy & 9.68 & 2.27 & 23.46 & 9.16 & 2.18 & 23.84 \\
\hline Ho & 1.85 & 0.34 & 18.44 & 1.87 & 0.37 & 19.72 \\
\hline Er & 4.99 & 0.76 & 15.27 & 5.40 & 0.89 & 16.41 \\
\hline Tm & 0.77 & 0.09 & 11.10 & 0.86 & 0.10 & 11.87 \\
\hline Yb & 5.18 & 0.45 & 8.67 & 5.82 & 0.54 & 9.20 \\
\hline Lu & 0.74 & 0.06 & 8.27 & 0.86 & 0.07 & 7.97 \\
\hline Y & 44.60 & 6.52 & 14.62 & 53.20 & 9.50 & 17.86 \\
\hline $\mathbf{\Sigma R E E}$ & 599.12 & 114.25 & 19.07 & 593.77 & 278.32 & 46.87 \\
\hline $\boldsymbol{\Sigma}$ LREE & 513.62 & 98.01 & 19.08 & 503.97 & 260.72 & 51.73 \\
\hline $\mathbf{\Sigma H R E E}$ & 85.50 & 16.24 & 18.99 & 89.80 & 17.60 & 19.60 \\
\hline
\end{tabular}

Note: $\Sigma$ REE are La-Lu and Y, LREE are La-Sm and HREE are Eu-Lu and Y (Wall, 2014)

Our preliminary results suggest that up to $\sim 50 \%$ of the total REE in bauxite (especially in the upper parts of the weathered profile) could be leached easily using ammonium sulphate (Table 1 and Figure 1). Consequently, leaching 100-300 ppm of REE directly from bauxite results in consuming fewer and cheaper reagents compared with red muds, where large amounts of strong acids and long digestion time periods are needed to leach high proportions (almost 80\%) of REE (e.g Borra et al., 2015). The high costs of acids needed for leaching as well as the low HREE contents of Greek red muds seem problematic for an economically feasible REE extraction. Moreover, the disposal of the acids used may have important environmental implications. The most important benefit of the suggested method is that it is less likely to interfere with the Bayer process because it may be easy to install and run in the plant at the point where bauxite is gathered, right before passing through the Bayer process.

The preliminary results presented in this study also indicate that the easily leachable REE in Greek bauxite, extracted using ammonium sulphate, may occur as ion-adsorbed phases, i.e. mainly as ions 
adsorbed onto phases such as kaolinite, illite and chamosite, which are present in Greek bauxite (Tsirambides and Filippidis, 2012; Laskou and Economou-Eliopoulos, 2013). These REE phases will not be retained in the solid phase after the bauxite passes the Bayer process, due to the ore processing in a concentrated sodium hydroxide $(\mathrm{NaOH})$ solution at various temperatures and pressures (Power et al., 2011; Binnemans et al., 2015). It is therefore likely that an ammonium sulphate leaching method may not be efficient in removing REE for red mud waste.

\section{Conclusions}

Our pilot study suggests that some amounts of REE could be leached in a simple and cheap way by taking advantage of some easily leachable REE phases occurring in bauxite. Even if those amounts are relatively small, application of this method could result in further income for Aluminium of Greece S.A., in addition to the induction of Greece and hence EU in the rare earth oxide (REO) production chain. However, further research focused on improved characterization of bauxite and red mud waste phases, selective mining of REE enriched bauxites, and the development of efficient REE recovery techniques from bauxites and red muds, is required to fully assess these potentially important resources.

\section{Acknowledgements}

The authors would like to thank Delphi-Distomon S.A. (subsidiary of Aluminium of Greece S.A.) for permitting the collection of bauxite samples. The British Geological Survey (BGS) laboratories are also gratefully acknowledged.

\section{References}

Bao, Z. and Zhao, Z., 2008. Geochemistry of mineralization with exchangeable REY in the weathering crusts of granitic rocks in South China, Ore Geology Reviews, 33, 519-535.

Binnemans, K., Jones, P.T., Blanpain, B., Van Gerven, T. and Pontikes, Y., 2015. Towards zerowaste valorisation of rare-earth-containing industrial process residues: a critical review. Journal of Cleaner Production, 99, 17-38.

Binnemans, K., Pontikes, Y., Jones, P.T., Van Gerven, T. and Blanpain, B., 2013. Recovery of rare earths from industrial waste residues: a concise review. In: Proceedings of the $3 \mathrm{rd}$ International Slag Valorisation Symposium: The Transition to Sustainable Materials Management, Leuven, Belgium, 191-205.

Borra, C.R., Pontikes, Y., Binnemans, K. and Van Gerven, T., 2015. Leaching of rare earths from bauxite residue (red mud), Minerals Engineering, 76, 20-27.

Chakhmouradian, A.R. and Wall, F., 2012. Rare earth elements: minerals, mines, magnets (and more). Elements: an international magazine of mineralogy, geochemistry, and petrology, 8, 333-340.

Chi, R. and Tian, J., 2008. Weathered crust elution-deposited rare earth ores, New York, Nova Science Publishers, 288 pp.

Dangić, A., 1988. Kaolinization of bauxite: a study of the Vlasenice bauxite area, Yugoslavia, II. Alteration of oolites, Clays and Clay Minerals, 36(5), 439-447.

Deady, É., Mouchos, E., Goodenough, K., Williamson, B. and Wall, F., 2014. Rare earth elements in karst-bauxites: a novel untapped European resource? ERES $1^{\text {st }}$ European Rare Earth Resources conference, Milos, Greece.

European Commission, 2014. Report on critical raw materials for the EU. Report of the Ad Hoc Working Group on defining critical raw materials, $41 \mathrm{pp}$.

Freyssinet, Ph., Butt, C.R.M. and Morris, R.C., 2005. Ore-forming processes related to lateritic weathering, Econ. Geol., 100th Anniversary Volume, 681-722.

Fulford, G.D., Lever, G. and Sato, T., 1991. Recovery of rare earth elements from red mud, BR9001453A. Gamaletsos, P., Godelitsas, A., Mertzimekis, T.J., Göttlicher, J., Steininger, R., Xanthos, S., Berndt, J., Klemme, S., Kuzmin, A. and Bárdossy, G., 2011. Thorium partitioning in Greek industrial bauxite investigated by synchrotron radiation and laser-ablation techniques. Nuclear 
Instruments and Methods in Physics Research Section B: Beam Interactions with Materials and Atoms, 269, 3067-3073.

Gamaletsos, P.N., Godelitsas, A., Kasama, T., Kuzmin, A., Lagos, M., Mertzimekis, T.J., Göttlicher, J., Steininger, R., Xanthos, S., Pontikes, Y., Angelopoulos, G.N., Zarkadas, C., Komelkov, A., Tzamos, E. and Filippidis, A., 2016. The role of nano-perovskite in the negligible thorium release in seawater from Greek bauxite residue (red mud), Sci. Rep., 6, 21737, doi: 10.1038/srep21737.

Kynicky, J., Smith, M.P. and Xu, C., 2012. Diversity of rare earth deposits: the key example of China. Elements: an international magazine of mineralogy, geochemistry, and petrology, 8, 361-367.

Laskou, M. and Andreou, G., 2003. Rare earth element distribution and REE-minerals from the Parnassos-Ghiona bauxite deposits, Greece, Biennial Society for Geology Applied to Mineral Deposits Meeting, 7th, Mineral Exploration and Sustainable Development, Athens, Greece, 2003, Conference Proceedings, 89-92.

Laskou, M. and Economou-Eliopoulos, M., 2013. Bio-mineralization and potential biogeochemical processes in bauxite deposits: genetic and ore quality significance, Mineralogy and Petrology, 407(4), 171-186.

MacDonough, W.F. and Sun, S.-S., 1995. The composition of the Earth, Chemical Geology, 120, 223-253.

Maksimović, Z. and Pantó, G., 1996. Authigenic rare earth minerals in karst-bauxites and karstic nickel deposits. In: Jones, A.P., Wall, F. and Williams, C.T., eds., Rare earth minerals, chemistry, origin and ore deposits, Chapter 10, 257-279.

Moldoveanu, G. and Papangelakis, V.G., 2012. Recovery of rare earth elements adsorbed on clay minerals: I. Desorption mechanism, Hydrometallurgy, 117-118 71-78.

Ochsenkühn-Petropoulou, M., Lyberopoulou, Th. and Parissakis, G., 1994. Direct determination of lanthanides, yttium and scandium in bauxites and red mud from alumina production, Analytica Chimica Acta, 296(3), 305-313.

Ochsenkühn-Petropulou, M., Ochsenkühn, K. and Luck, J., 1991. Comparison of inductively coupled plasma mass spectrometry with instrumental neutron activation analysis for the determination of rare earth elements in Greek bauxites, Spectrochim. Acta, 46, 51-65.

Ochsenkühn-Petropulu, M., Lyberopulu, T., Ochsenkühn, K.M. and Parissakis, G., 1996. Recovery of lanthanides and yttrium from red mud by selective leaching, Analytica Chimica Acta, 319, 249-254.

Power, G., Gräfe, M. and Klauber, C., 2011. Bauxite residue issues: I. Current management, disposal and storage practices, Hydrometallurgy, 108, 33-45.

Rauret, G., López-Sànchez, J.F., Sahuquillo, A., Barahona, E., Lachica, M., Ure, A.M., Davidson, C.M., Gomez, A., Lück, D., Bacon, J., Yli-Halla, M., Muntau, H. and Quevauviller, Ph., 2000. Application of a modified BCR sequential extraction (three-step) procedure for the determination of extractable trace metal contents in a sewage sludge amended soil reference material (CRM 483), complemented by a three-year stability study of acetic acid and EDTA extractable metal content, J. Environ. Monit., 2, 228-233.

Rauret, G., López-Sánchez, J.F., Sahuquillo, A., Rubio, R., Davidson, C., Ure, A. and Quevauviller, Ph., 1999. Improvement of the BCR three step sequential extraction procedure prior to the certification of new sediment and soil reference materials, J. Environ. Monit., 1, 57-61.

Retallack, G.J., 2010. Lateritization and bauxitization events, Economic Geology, 105, 655-667.

Sanematsu, K., Kon, Y., Imai, A., Watanabe, K. and Watanabe, Y., 2013. Geochemical and mineralogical characteristics of ion-adsorption type REE mineralization in Phuket, Thailand, Miner. Deposita, 48, 437-451.

Tsirambides, A. and Filippidis, A., 2012. Metallic mineral resources of Greece, Central European Journal of Geosciences, 4(4), 641-650.

U.S. Geological Survey, 2015. Mineral commodity summaries 2015. Reston, VA, U.S. Geological Survey, 196.

Valeton, I., Bierman, M., Reche, R. and Rosenberg, F.F., 1987. Genesis of nickel laterites and bauxites in Greece during the Jurassic and the Cretaceous and their relation to ultrabasic rocks, Ore Geol. Rev., 2, 359-404.

Wall, F., 2014. Rare earth elements. In: Gunn, G., Critical Metals Handbook, Chapter 13, 312-339.

Wall, F., Mouchos, E. and Loye, E., 2014. Processing weathered REE deposits. Geology to Metallurgy of Critical Rare Earths (GEM-CRE). Workshop 3, Camborne School of Mines, UK. 